\title{
Nitrogen and calcium fertilization on the growth and development of gerbera cultivated in pots for cut flowers
}

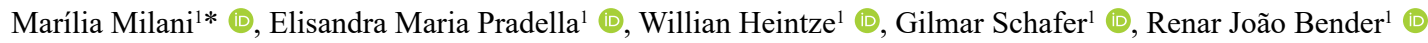 \\ ${ }^{1}$ Universidade Federal do Rio Grande do Sul, Departamento de Horticultura e Silvicultura, Faculdade de Agronomia, Porto Alegre-RS, Brazil.
}

\begin{abstract}
Gerbera is a flowering species with relevance to the cut flower market. Understanding nutritional requirements of the species is important to improve fertilization procedures. In the present work, our objective was to evaluate the influence of different doses of nitrogen $(\mathrm{N})$ and calcium $(\mathrm{Ca})$ on the growth and development of gerbera cultivated in pots as a cut flower. The experiment was conducted in a protected environment in a bifactorial design, with an additional treatment consisting of the combination of three $\mathrm{N}$ (0.07, 0.15 and $0.2 \mathrm{~g} \mathrm{~L}^{-1}$ substrate) and $\mathrm{Ca}\left(0.02,0.03\right.$ and $0.04 \mathrm{~g} \mathrm{~L}^{-1}$ substrate) doses applied every 15 days. Control plants were not supplemented with either $\mathrm{N}$ or $\mathrm{Ca}$. No significant interaction between $\mathrm{N}$ and $\mathrm{Ca}$ doses was observed. The highest number of flower stalks was obtained with $0.15 \mathrm{~g} \mathrm{~N} \mathrm{~L}^{-1}$ substrate and $0.04 \mathrm{~g} \mathrm{Ca} \mathrm{L}^{-1}$ substrate. Flower diameter, plant leaf area and total chlorophyll contents were at a maximum of $0.14 \mathrm{~g} \mathrm{~N} \mathrm{~L}^{-1}$ substrate and $0.04 \mathrm{~g} \mathrm{Ca} \mathrm{L}^{-1}$ substrate. $\mathrm{N}$ and Ca doses influenced in an independent manner the growth and development of gerberas as a cut flower cultivated in pots, and we determined that its fertilization should occur every 15 days with $0.34 \mathrm{~g} \mathrm{~N} \mathrm{~L}^{-1}$ substrate and $0.04 \mathrm{~g} \mathrm{Ca} \mathrm{L}^{-1}$ substrate.
\end{abstract}

Keywords: Gerbera hybrida Hort.; floriculture; plant nutrition; mineral nutrition; substrate.

\section{RESUMO}

Adubação com nitrogênio e cálcio no crescimento e desenvolvimento de gérbera de corte cultivada em recipientes A gérbera é uma das espécies floríferas com destaque no mercado de flores de corte. Conhecer suas necessidades nutricionais torna-se importante para melhorar a eficiência da adubação. O objetivo do presente trabalho foi avaliar a influência de diferentes doses de nitrogênio $(\mathrm{N})$ e cálcio $(\mathrm{Ca})$ no crescimento e desenvolvimento de plantas de gérbera de corte cultivadas em recipientes. $\mathrm{O}$ experimento foi conduzido em ambiente protegido, tipo abrigo, em esquema bifatorial com tratamento adicional, que consistiu da combinação de três doses de $\mathrm{N} \mathrm{L}^{-1}$ de substrato $(0,07,0,15$ e $0,2 \mathrm{~g})$ e de três doses de $\mathrm{Ca} \mathrm{L}^{-1}$ de substrato $(0,02,0,03 \mathrm{e} 0,04 \mathrm{~g})$, aplicadas a cada 15 dias, além da testemunha, sem adubação com $\mathrm{N}$ e Ca. Não houve efeito significativo da interação entre as doses de $\mathrm{N}$ e Ca. A maior produção de hastes florais planta ${ }^{-1}$ foi obtida com as doses de $0,15 \mathrm{~g}_{\text {de N L}}^{-1}$ de substrato e $0,04 \mathrm{~g} \mathrm{de} \mathrm{Ca} \mathrm{L-1}^{-1 e}$ substrato. $\mathrm{O}$ diâmetro do capítulo, a área foliar planta $^{-1} \mathrm{e}$ o teor de clorofila total planta ${ }^{-1}$ foram máximos com as doses de $0,14 \mathrm{~g}$ de $\mathrm{N} \mathrm{L}^{-1}$ de substrato e $0,04 \mathrm{~g}_{\text {de }} \mathrm{Ca} \mathrm{L}^{-1}$ de substrato. As diferentes doses de nitrogênio e cálcio influenciam, de maneira independente, o crescimento e o desenvolvimento de plantas de gérbera de corte cultivadas em recipientes, e recomenda-se o uso, a cada 15 dias,

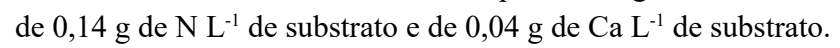

Palavras-chave: Gerbera hybrida Hort.; floricultura; nutrição de plantas; nutrição mineral; substrato.

\section{Introduction}

Gerbera (Gerbera hybrida Hort.) is a prominent species for the fresh cut flower market. Nevertheless, there are still demands for information on quality and quantity increments of this species, and one of gerbera's culture requirements for rightful handling concerns the appropriate fertilization (Santos et al., 2016).
The success in gerbera production and floral stalk quality over the years depends on environmental elements: temperature, relative humidity, incident solar radiation and the interactions amongst those. Furthermore, adequate cultural practices, such as precise fertilization procedures, also affect the outcome of cut flower production (Mercurio, 2002).

Therefore, a correct nutrient equilibrium is of utmost importance, as incorrect fertilizer applications could result

*Corresponding author: mariliakmilani@gmail.com 
in nutrient deficiencies and hold back plant development, thus affecting floral stalk production as a consequence of reduced photoassimilate synthesis, especially carbohydrates (Castro et al., 2007).

Amongst the nutrients, nitrogen $(\mathrm{N})$ is the most required for vegetables, and it is related to physiological processes: photosynthesis, respiration, development and root activity (Taiz et al., 2017). Therefore, applying appropriate levels of $\mathrm{N}$ fertilizer according to the different kinds of production systems can improve plant growth and flowering quality (Lin et al., 2019).

Calcium $(\mathrm{Ca})$ is essential for membrane permeability and cell wall structural integrity, and its presence in cell walls imparts mechanical resistance, contributing to increases in cut flower longevity (Taiz et al., 2017).

Nitrogen $(\mathrm{N})$ is an essential nutrient for both the vegetative and reproductive phases of gerbera plants. Its contribution is decisive for floral stalk development. For the same reason, $\mathrm{Ca}$ has to be delivered along the whole plant cycle of potted gerbera plants (Ludwig et al., 2008).

However, in Brazil, information on fertilization with $\mathrm{N}$ and $\mathrm{Ca}$ are not available for gerberas cultivated for long periods in pots with organic substrate. With that in mind, the present work intends to evaluate different doses of nitrogen and calcium on the growth and development of gerberas cultivated in recipients.

\section{Material and Methods}

The experiment was conducted in a protected environment, covered with a low density polyethylene film of 150 micra with an incorporated ultraviolet (UV) additive. The gerberas were cultivated in that ambient from April 19, 2013, until August 29, 2015. During the summer months, when light intensity was higher than 60,000 lux, a reflective aluminum net with $50 \%$ shading was placed over the plants.

Gerbera plantlets of the cv. Dino were obtained from specialized grower. The 16 week old plants had, on average, seven fully expanded leaves. The floral stalk was considered a complete inflorescence, i. e., stalk and capitulum with flowers and the associated ligulas, referred to as petals. The plantlets were transplanted into plastic pots, one plant pot $^{-1}$ of $15 \mathrm{~cm}$ height and $2.8 \mathrm{~L}$ volume, filled with commercial pinus bark-based substrate. The conductivity and $\mathrm{pH}$ (in water) of the substrate determined through the 1:5 dilution method (Brasil, 2007) on the day of the experiment's installation were $0.28 \mathrm{mS} \mathrm{cm}^{-1}$ and 6.37 , respectively.

Dry and humid densities were $342.76 \mathrm{~kg} \mathrm{~m}^{-1}$ and 584.56 $\mathrm{kg} \mathrm{m}^{-1}$, respectively. Total porosity, aeration space, available water and remaining water, determined according to De Boodt and Verdonck (1972) were, in this order, $77.46 \%$, $27.22 \%, 14.60 \%$ and $35.65 \%$.

The experiment was conducted in a randomized block design with four replicates, and analyzed as bifactorial with an additional treatment $[(3 \times 3)+1]$ : a combination of three doses of $\mathrm{N}(0.07,0.15 \mathrm{e} 0.2 \mathrm{~g})$ and $\mathrm{Ca}(0.02,0.03 \mathrm{e}$ $0.04 \mathrm{~g})$ for every liter of substrate. The control treatment wasn't supplied with $\mathrm{N}$ or $\mathrm{Ca}$. The experimental units had eight plants, resulting in a total of 320 plants, arranged in a density of 11 plants $\mathrm{m}^{-1}$.

After 27 days of transplant, the fertilization plan was started and ended 833 days after. The plants received all the nutrients diluted in water, of which $50 \mathrm{~mL}$ were delivered manually to every pot every 15 days.

Each pot was irrigated by means of a drip irrigation system, at a flow rate of $0.46 \mathrm{~L} \mathrm{~h}^{-1}$. During the autumn and winter, the plants were irrigated three times a week for about three minutes, in only one cycle a day. In the spring, the plants were irrigated every day and again for one single cycle of three minutes. In the summer, the plants were also irrigated every day, but then divided in three times a day, resulting in a total of seven minutes of water delivery. The irrigation water presented an average $\mathrm{pH}$ of 6.53 and $116.20 \mu \mathrm{S} \mathrm{cm}^{-1}$ conductivity.

The $\mathrm{N}$ and $\mathrm{Ca}$ doses were applied in the form of ammonium nitrate $\left(30 \%\right.$ total $\left.\mathrm{N}: 15 \% \mathrm{NO}_{3}^{-}+15 \% \mathrm{NH}_{4}^{+}\right)$ and calcium nitrate $\left(15.5 \% \mathrm{NO}_{3}^{-}+19 \% \mathrm{Ca}\right)$. At the end of the experiment, a total of 3.94, 8.58 and $11.83 \mathrm{~g} \mathrm{~N} \mathrm{~L}^{-1}$ substrate and $0.93,186$ and $2.55 \mathrm{~g} \mathrm{Ca} \mathrm{L}^{-1}$ substrate had been supplied.

A complementary fertilization was performed, in which all the plants were fertilized with the same doses of potassium $(\mathrm{K})$, phosphorus $(\mathrm{P})$ and magnesium $(\mathrm{Mg})$ along the vegetative growth period. A total of $0.08 \mathrm{~g} \mathrm{~L}^{-1}$ substrate of $\mathrm{K}$ was supplied to every plant. Likewise, $0.32 \mathrm{~g} \mathrm{~L}^{-1}$ substrate of $\mathrm{P}$ and $0.02 \mathrm{~g} \mathrm{~L}^{-1}$ substrate of $\mathrm{Mg}$ had been applied for the whole period to every gerbera plant.

After 91 days of transplant, the flowering period started. At that time, $80 \%$ of plants displayed a visible capitulum of about $1 \mathrm{~cm}$, the fertilization with macronutrients was readjusted and the plants started to be supplied as well with micronutrients.

The amounts of $\mathrm{P}, \mathrm{K}$ and $\mathrm{Mg}$ summed up to 1.63, 8.77 and $0.61 \mathrm{~g} \mathrm{~L}^{-1}$ substrate, respectively. Additionally, $5.1 \mathrm{~g} \mathrm{~L}^{-1}$ substrate of the commercial formulation Rexolin ${ }^{\circledR}$, containing $11.6 \%$ potassium oxide $\left(\mathrm{K}_{2} \mathrm{O}\right), 1.28 \%$ sulfur $(\mathrm{S})$, $0.86 \% \mathrm{Mg}, 2.1 \%$ boron $(\mathrm{B}), 0.36 \%$ copper $(\mathrm{Cu}), 2.66 \%$ iron (Fe), 2.48\% manganese (Mn), 0.036\% molybdenum (Mo) and $3.38 \%$ Zinc $(\mathrm{Zn})$ was applied to the plants. The sources of macronutrients applied to the gerberas were: potassium chloride $\left(60 \% \mathrm{~K}_{2} \mathrm{O}+45 \%\right.$ chlorine $\left.(\mathrm{Cl})\right)$, monopotassium phosphate $\left(52 \%\right.$ phosphorus pentoxide $\left.\left(\mathrm{PO}_{5}\right)+34 \% \mathrm{~K}_{2} \mathrm{O}\right)$ and magnesium sulphate $(9 \% \mathrm{Mg})$.

The floral stalks were harvested every week at the commercial harvesting point, as described in Oliveira et al. (2012). From each flower stalk, the length and the diameter of the capitulum were determined. The stalk diameter was determined $20 \mathrm{~cm}$ down the inflorescence and results were expressed in mm (Milani et al., 2019).

849 days after transplant, when the plants had completed two years of production, 15 completely expanded leaves were collected from every treatment to be analyzed for macronutrients determination, and the leaves had been dried until constant weight at $65^{\circ} \mathrm{C}$.

At the end of the experiment, 862 days after transplant, total chlorophyll content was determined from two fully 
expanded leaves of two plants from every experimental unit. For that measurement, the electronic equipment clorofiLOG, model CFL1030 $\left(\right.$ Falker $\left.^{\circledR}\right)$ was used. The results are expressed as Falker Chlorophyll Index. The total number of floral stalks harvested from every plant and the total amount of leaves were recorded at that time. The leaf area $\left(\mathrm{cm}^{2}\right.$ plant $\left.{ }^{-1}\right)$ was measured via destructive method with a Licor model LI-3100. The amount of leaf dry mass $\left(\mathrm{g} \mathrm{plant}^{-1}\right)$ was determined from the tissues dried until constant weight at $65^{\circ} \mathrm{C}$.

The data from all the variables was submitted to analysis of variance at $\mathrm{p}<0.05$ and, afterwards, for regression analysis for $\mathrm{N}$ and $\mathrm{Ca}$ doses, using the statistical package Sisvar (Ferreira, 2020). Also, a linear Pearson correlation at $\mathrm{p}<0.05$ was performed, concerning the evaluated characteristics and macronutrient contents of the gerbera leaves, using the statistical software Action (Estatcamp, 2020).

\section{Results and Discussion}

The analysis of variance did not indicate a significant effect for the interaction of $\mathrm{N}$ doses and $\mathrm{Ca}$ doses regarding any of the evaluated parameters. Therefore, only the main effects were considered for every parameter. Regarding macronutrient contents of gerbera leaves, a polynomial quadratic adjustment of the data was determined for total $\mathrm{N}$ in response to the doses of $\mathrm{N}$ applied along the growing period (Figure 1A).

The maximum contents of $34.34 \mathrm{~g} \mathrm{~kg}^{-1}$ dry matter were determined when $0.13 \mathrm{~g} \mathrm{~L}^{-1}$ substrate were supplied every 15 days. At the highest dose of $\mathrm{N}$, a reduction of
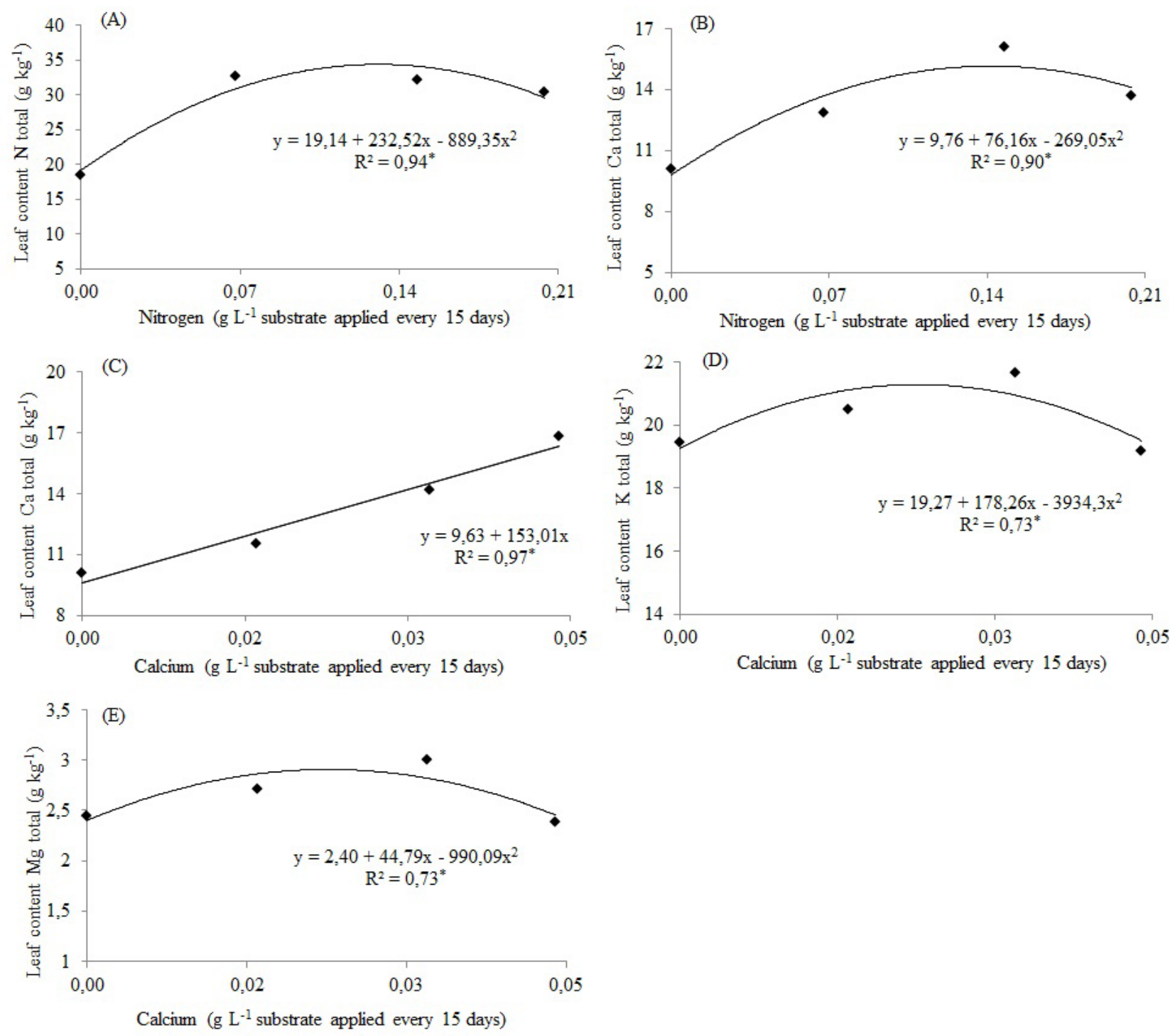

*Significant at $\mathrm{p}<0.05$.

Figure 1. Leaf contents ( $\mathrm{g} \mathrm{kg}^{-1}$ dry mass) in gerberas cv. Dino cultivated in pots: total nitrogen (N) contents (A) and total calcium (Ca) contents (B) in response to different doses of $\mathrm{N}$ ( $\mathrm{g} \mathrm{L}^{-1}$ substrate applied every 15 days); total Ca contents $(\mathrm{C})$, total potassium $(\mathrm{K})$ contents $(\mathrm{D})$ and total magnesium $(\mathrm{Mg})$ contents $(\mathrm{E})$ in response to different doses of $\mathrm{Ca}\left(\mathrm{g} \mathrm{L}^{-1}\right.$ substrate applied every 15 days). 
that nutrient's contents was determined, probably as a result of the remainders of the nonabsorbed $\mathrm{N}$ by plants being directed into the substrate. Another possibility is that nitrate leaching of nonplant-absorbed N-fertilizer into the substrate might have occurred.
The efficiency of $\mathrm{N}$ uses decreases as the dose of that nutrient increases. Overall, that statement was confirmed in the evaluated characteristics from the gerberas of the present experiment as they were reduced with the highest $\mathrm{N}$ dose tested (Figures 2A, 2C, 2E and 2G, 3A, 3C, 3E and 3G).
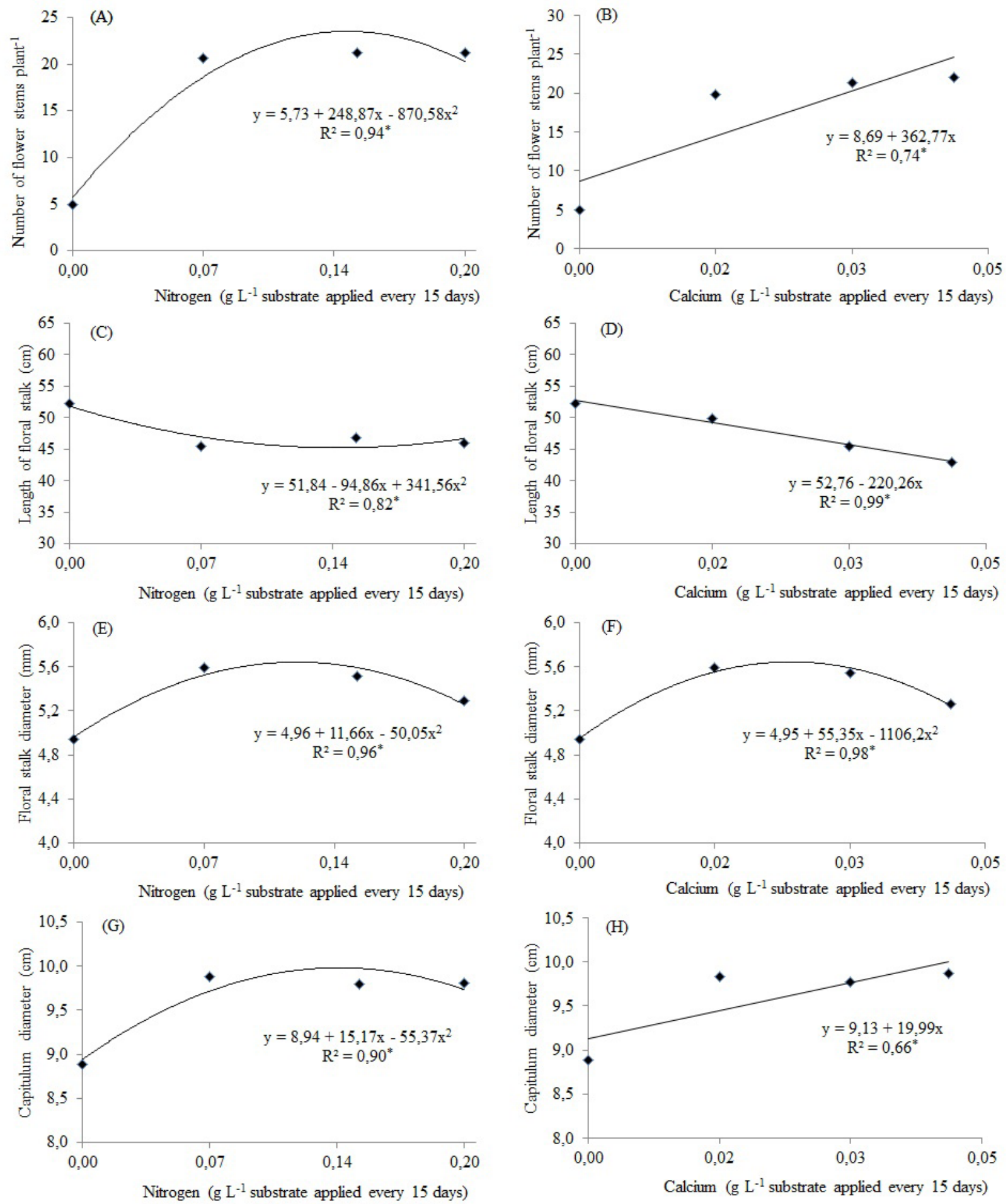

*Significant at $\mathrm{p}<0.05$.

Figure 2. Yield and quality of floral stalks of cv. Dino gerberas cultivated in pots with different doses of nitrogen (N) and calcium $(\mathrm{Ca})\left(\mathrm{g} \mathrm{L}^{-1}\right.$ substrate applied every 15 days): number of flower stems plant ${ }^{-1}$ with different doses of $\mathrm{N}$ (A) and $\mathrm{Ca}(\mathrm{B})$; length of floral stalk (cm) with different doses of $\mathrm{N}(\mathrm{C})$ and $\mathrm{Ca}(\mathrm{D})$; floral stalk diameter (mm) with different doses of $\mathrm{N}(\mathrm{E})$ and $\mathrm{Ca}(\mathrm{F})$ and capitulum diameter $(\mathrm{cm})$ with different doses of $\mathrm{N}(\mathrm{G})$ and $\mathrm{Ca}(\mathrm{H})$. 

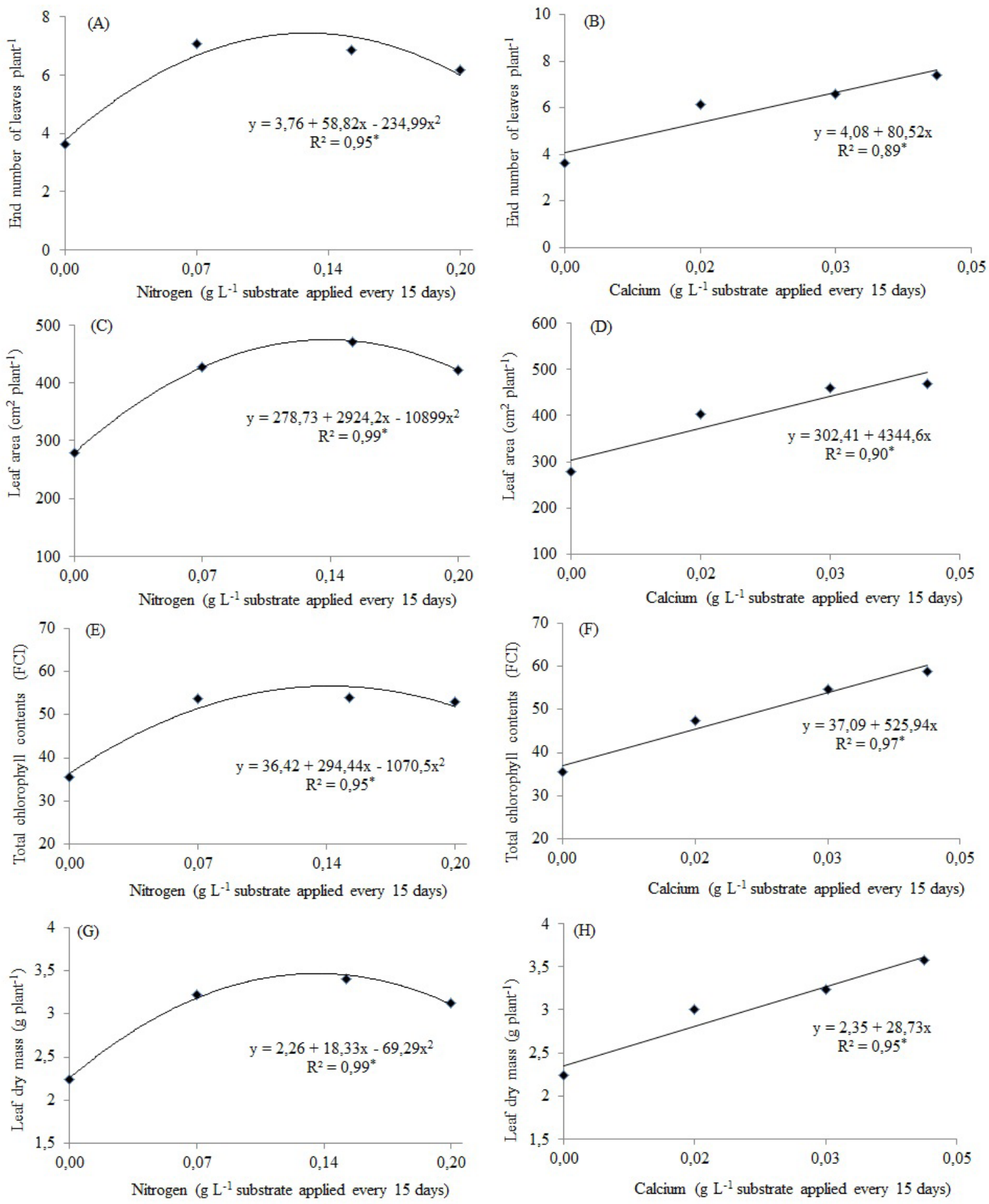

*Significant at $\mathrm{p}<0.05$.

Figure 3. Gerberas cv. Dino cultivated in pots and supplied every 15 days with different doses of nitrogen $(N)\left(g L^{-1}\right.$ substrate) and calcium (Ca) ( $\mathrm{g} \mathrm{L}^{-1}$ substrate): end number of leaves plant ${ }^{-1}$ in response to different doses of $\mathrm{N}(\mathrm{A})$ and (B); leaf area $\left(\mathrm{cm}^{2}\right.$ plant $\left.{ }^{-1}\right)$ in response to different doses of $\mathrm{N}(\mathrm{C})$ and $\mathrm{Ca}(\mathrm{D})$; total chlorophyll contents (FCI) in response to different doses of $\mathrm{N}(\mathrm{E})$ and $\mathrm{Ca}(\mathrm{F})$; and leaf dry mass $\left(\mathrm{g}_{\text {plant }}{ }^{-1}\right)$ in response to different doses of $\mathrm{N}(\mathrm{G})$ and $\mathrm{Ca}(\mathrm{H})$.

In the control plants, an average leaf $\mathrm{N}$ content of $19.14 \mathrm{~g} \mathrm{~kg}^{-1}$ was determined (Figure 1A), an indication that the substrate was a source of $\mathrm{N}$ deriving from the mineralization process of the organic matter of that substrate. Nonetheless, that amount is below the range of
$27 \mathrm{~g} \mathrm{~kg}^{-1}$ up to $32 \mathrm{~g} \mathrm{~kg}^{-1}$, suggested by Mercurio (2002) for gerberas as cut flower, an explanation for a slighter growth and development of these control plants.

The $\mathrm{Ca}$ contents in gerbera leaves also responded to doses of $\mathrm{N}$ applied in the fertilizations. A significant 
quadratic adjustment of the data was possible. At the dose of $0.14 \mathrm{~g} \mathrm{~L}^{-1}$ substrate, a maximum Ca content of $15.15 \mathrm{~g} \mathrm{~kg}^{-1}$ was determined (Figure 1B).

The foliar contents of $\mathrm{P}, \mathrm{K}, \mathrm{Mg}$ and $\mathrm{S}$ in response to $\mathrm{N}$ did not adjust to any polynomial model. The average values of these nutrients were equal to: $3.8 \mathrm{~g} \mathrm{~kg}^{-1}, 19.23 \mathrm{~g} \mathrm{~kg}^{-1}$, $2.83 \mathrm{~g} \mathrm{~kg}^{-1}$ and $3.08 \mathrm{~g} \mathrm{~kg}^{-1}$, respectively. However, there was a significant correlation between $\mathrm{P}$ and $\mathrm{K}$ contents $(\mathrm{r}=0.76), \mathrm{P}$ and $\mathrm{Mg}(\mathrm{r}=0.52), \mathrm{P}$ and $\mathrm{S}(\mathrm{r}=0.92), \mathrm{K}$ and $\mathrm{Mg}(\mathrm{r}=0.56)$ and $\mathrm{K}$ and $\mathrm{S}(\mathrm{r}=0.80)$, an indication that one nutrient affected positively the concentration of the other in the gerbera leaves.

Concerning the $\mathrm{Ca}$ doses in the fertilization program for gerberas in the present experiment, no significant adjustment to a polynomial model for $\mathrm{N}$ contents in leaves was possible. The average value for $\mathrm{N}$ in leaves was $24.25 \mathrm{~g} \mathrm{~kg}^{-1}$.

The foliar concentration of Ca was affected by the doses of Ca supplemented to the substrate, a significant positive linear effect (Figure 1C). The highest dose of $0.04 \mathrm{~g} \mathrm{Ca} \mathrm{L}^{-1}$ substrate applied every 15 days presented the highest foliar concentration of $\mathrm{Ca}: 15.75 \mathrm{~g} \mathrm{~kg}^{-1}$. In the control plants, an average value of $9.63 \mathrm{~g} \mathrm{~kg}^{-1}$ indicates that the substrate was a source of that nutrient for the gerberas. That value is below the critical limit of $16.6 \mathrm{~g} \mathrm{~kg}^{-1}$ proposed by Mercurio (2002). Nonetheless, no symptoms of deficiency were observed, but pointed towards a more moderate growth and development of these control plants (Figures 2B, 2D, 2F and $2 \mathrm{H}, 3 \mathrm{~B}, 3 \mathrm{D}, 3 \mathrm{~F}$ and $3 \mathrm{H}$ ).

The foliar contents of $\mathrm{K}$ of the gerberas revealed an influence of the applied $\mathrm{Ca}$ doses. A significant quadratic adjustment of the data was determined. At the dose of $0.02 \mathrm{~g} \mathrm{Ca} \mathrm{L}^{-1}$ substrate, a maximum $\mathrm{K}$ content of $21.27 \mathrm{~g} \mathrm{~kg}^{-1}$ was verified, which was followed by a decrease, as the doses of $\mathrm{Ca}$ increased (Figure 1D). These leaf $\mathrm{K}$ contents determined were below that indicated by Ludwig et al. (2019), which were above $40.8 \mathrm{~g} \mathrm{~kg}^{-1}$, depending on the cultivar or substrate used.

Therefore, from the point of maximum $\mathrm{Ca}^{2+}$ concentration, probably the $\mathrm{K}$ contents reduced via the competitive inhibition, as, with increasing $\mathrm{Ca}$ doses, a higher $\mathrm{Ca}$ content was determined, but the $\mathrm{K}$ content

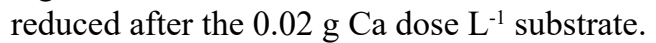

In that same directive, a significant quadratic adjustment was determined for $\mathrm{Ca}$ doses related to the contents of $\mathrm{Mg}$ in gerbera leaves (Figure 1E). The maximum content of $2.9 \mathrm{~g} \mathrm{~kg}^{-1}$ was determined at the dose of $0.02 \mathrm{~g} \mathrm{Ca} \mathrm{L}^{-1}$ substrate applied every 15 days. That result is probably a reduction in $\mathrm{Mg}$ concentration, taking place because of competitive $\mathrm{Ca}$ doses that were observed at the point of maximum dose. Foliar contents of $\mathrm{P}$ and $\mathrm{S}$ in gerbera leaves did not fit significantly into any polynomial model in response to $\mathrm{Ca}$ doses. The average values were determined as $3.8 \mathrm{~g} \mathrm{~kg}^{-1}$ and $3.08 \mathrm{~g} \mathrm{~kg}^{-1}$, respectively.

With regards to the parameter of total number of floral stalks of every gerbera plant, a significant quadratic adjustment for $\mathrm{N}$ doses and a linear positive effect for $\mathrm{Ca}$ doses were determined (Figure $2 \mathrm{~A}$ and $2 \mathrm{~B}$ ). At the dose of $0.14 \mathrm{~g} \mathrm{~N} \mathrm{~L}^{-1}$ substrate, a maximum of 24 floral stalks was harvested. At the dose of $0.04 \mathrm{~g} \mathrm{Ca} \mathrm{L}^{-1}$ substrate, 23 floral stalks were harvested from each plant.

Control plants yielded, on average, 18 floral stalks less than the plants fertilized with both $\mathrm{N}$ and $\mathrm{Ca}$. AlbinoGarduño et al. (2008) concluded that the number of gerbera flower stalks of plants in $15 \mathrm{~L}$ recipients was reduced in $60 \%$ to $70 \%$ in the presence of low $\mathrm{Ca}$ concentration (120 $\mathrm{mg} \mathrm{L}^{-1}$ ).

A significant correlation was observed in between the number of floral stalks and $\mathrm{N}$ contents in the leaves $(\mathrm{r}=0.72)$. Also, there was a significant correlation between the number of floral stalks and the final number of leaves $(\mathrm{r}=0.56)$ and between the final number of leaves and $\mathrm{N}$ contents in the leaves $(\mathrm{r}=0.55)$. That is a clear indication that, with a higher number of leaves, a higher $\mathrm{N}$ concentration was available, and, with that, more assimilates were synthesized and directed towards a greater production of flowers.

Taking into account that gerberas as cut flowers are commercialized in bunches of 20 stalks, regardless of size, it is critical that the cultivation takes place with proper $\mathrm{N}$ and Ca fertilization. Farias et al. (2013) point out that flower and ornamental plants production is associated to many factors, but nutrition of plants is one of the main aspects influencing production, as it was also observed in the present experiment.

Moreover, when gerberas are used as cut flowers, the floral stalk is the end product; therefore, a higher number of floral stalks implies lower production costs and higher competitiveness and profitability (Paulino et al., 2013).

Regression analysis of length of floral stalks resulted in a positive quadratic adjustment of the data for $\mathrm{N}$ doses (Figure 2C) and a linear negative adjustment for $\mathrm{Ca}$ doses (Figure 2D). The control plants cultivated without $\mathrm{N}$ and Ca supply presented the greatest length of floral stalks: $51.84 \mathrm{~cm}$ and $52.76 \mathrm{~cm}$, respectively. According to the criteria established by Ibraflor (2020), stalks longer than $50 \mathrm{~cm}$ are considered long stalks.

An explanation for that result in the present experiment might be attributed to the fact that plants that were not fertilized with either $\mathrm{N}$ or $\mathrm{Ca}$ had a reduced number of floral stalks emitted, as discussed previously. Moreover, the period between every setoff of stalks was longer in comparison to the fertilized plants.

Therefore, more photoassimilates might have been translocated to the only stalk of the plant granting a longer stalk. Conversely, plants that had been fertilized with $\mathrm{N}$ and $\mathrm{Ca}$ always presented more than one stalk, giving rise to competition for photoassimilates, which were not sufficient to supply all the sinks (floral stalks) equally by the source (leaves). Taiz et al. (2017) state that the distribution of photoassimilates occurs, for the most part, in response to the amount and proximity of these organs.

Gerbera plants fertilized with $\mathrm{N}$ and Ca presented floral stalks shorter than $50 \mathrm{~cm}$ and, therefore, ranked as short stemmed flowers (Ibraflor, 2020), possibly a result of K deficiency, as the concentrations of that nutrient (Figure 1D) were below the range recommended by Mercurio (2002) of 31 to $36 \mathrm{~g} \mathrm{~kg}^{-1}$ and informed that $\mathrm{K}$ deficits hamper floral stalk length. 
The criterion established by Ibraflor (2020) indicates that gerberas as cut flowers should have a stalk diameter of 5 to $6 \mathrm{~mm}$. $\mathrm{N}$ doses presented an influence on that variable and significant quadratic adjustment was calculated. The highest average diameter of $5.64 \mathrm{~mm}$ was observed at an $\mathrm{N}$ dose of $0.12 \mathrm{~g} \mathrm{~N} \mathrm{~L}^{-1}$ substrate applied every 15 days (Figure 2E). For Ca doses, a quadratic adjustment of the data was also calculated. At a dose of $0.025 \mathrm{~g} \mathrm{Ca} \mathrm{L}^{-1}$, a maximum average stalk diameter was determined: $5.64 \mathrm{~mm}$ (Figure 2F). At that dose of $\mathrm{Ca}$, a maximum $\mathrm{K}$ foliar content was present, as observed in Figure 1D.

Regarding the diameter of the capitulum, the inflorescences are classified as large when the diameter is beyond $10 \mathrm{~cm}$ (Ibraflor, 2020). For that variable, a quadratic adjustment of the data in response to $\mathrm{N}$ doses was calculated. The maximum diameter of $10 \mathrm{~cm}$ was observed at a dose of $0.14 \mathrm{~g} \mathrm{~N} \mathrm{~L}^{-1}$ substrate (Figure 2G). For $\mathrm{Ca}$ doses, a positive linear adjustment was calculated, i.e., at the highest $\mathrm{Ca}$ dose $\left(0.04 \mathrm{~g} \mathrm{~L}^{-1}\right)$ the largest diameter $(10 \mathrm{~cm})$ of inflorescences was determined (Figure $2 \mathrm{H}$ ).

Oliveira et al. (2012) did not determine significant differences on the diameter of inflorescences of gerberas cultivated in $5 \mathrm{~L}$ recipients applying $\mathrm{Ca}$ doses of $7.5,10$ or $12.5 \mathrm{mMol} \mathrm{L}^{-1}$. Regression analysis for the variable final leaf number plant ${ }^{-1}$ in response to $\mathrm{N}$ doses indicated that the best adjustment was a negative quadratic adjustment of the data (Figure 3A).

With increases in the dose of $\mathrm{N}$, the final number of leaves also increased. The maximum increment of seven leaves was estimated at the dose of $0.13 \mathrm{~g} \mathrm{~N} \mathrm{~L}^{-1}$ substrate. Beyond that point of maximum increment, the tendency was a reduction of the final number of leaves on every gerbera plant.

The data for the number of leaves in response to the applied $\mathrm{Ca}$ doses resulted in a linear positive adjustment (Figure 3B), in which the highest final number of seven leaves plant $^{-1}$ was observed at the highest $\mathrm{Ca}$ dose (0.04 $\mathrm{g} \mathrm{L}^{-1}$ substrate).

Leaf area of gerbera plants presented a significant quadratic response to $\mathrm{N}$ doses. The maximum area of $474.69 \mathrm{~cm}^{2}$ was determined at $0.13 \mathrm{~g} \mathrm{~N} \mathrm{~L}^{-1}$ substrate (Figure 3C). For Ca doses, a positive linear adjustment of the data was calculated. The highest leaf area of $476.19 \mathrm{~cm}^{2}$ was determined at the highest Ca dose (Figure 3D).

A significant correlation of leaf area and foliar $\mathrm{N}$ contents was determined $(r=0.91)$. Sometimes a higher number of leaves on gerbera plants is associated to a smaller size of these leaves. That observation was not acknowledged in the present experiment, since a significant positive correlation was established among number of leaves and leaf area $(\mathrm{r}=0.88)$.

Total chlorophyll contents presented a significant quadratic response to $\mathrm{N}$ doses (Figure 3E). The maximum chlorophyll contents of 56.66 FCI was determined when $0.14 \mathrm{~g} \mathrm{~N} \mathrm{~L}^{-1}$ substrate were applied every 15 days to the gerbera plants.

For $\mathrm{Ca}$ doses, the total chlorophyll contents presented a significant positive quadratic response (Figure 3F). The maximum chlorophyll content was 58.13 FCI, with the highest $\mathrm{Ca}$ dose of $0.04 \mathrm{~g} \mathrm{Ca} \mathrm{L}^{-1}$ substrate. The control plants presented, on average, $63 \%$ less total chlorophyll, a result explained by the lack of nitrogen in the control plants, as that nutrient is essential for chlorophyll molecules synthesis. Moreover, $\mathrm{Ca}$ deficiencies result in losses of membrane integrity that might result in an increase in respiration rates and protein and chlorophyll degradation (Taiz et al., 2017).

Also, a significant correlation was observed between total chlorophyll contents and number of flower stems $(\mathrm{r}=0.65)$. Such a result is explained by the fact that plants with the highest chlorophyll index will have higher photosynthesis rates and, consequently, will be synthesizing more assimilates, leading to higher dry mass accumulation.

An accurate form to evaluate plant growth is through its dry mass content, since fresh weight is a variable sensitive to water contents oscillations (Taiz et al., 2017). For that reason, in relation to dry mass (DM) of the gerbera leaves, it is possible to determine a tendency for a significant quadratic adjustment for $\mathrm{N}$ doses. Applying, every 15 days, $0.13 \mathrm{~g} \mathrm{~N} \mathrm{~L}^{-1}$ substrate, a maximum of $3.47 \mathrm{~g} \mathrm{plant}^{-1}$ of leaf dry mass was determined (Figure $3 \mathrm{G}$ ). For the Ca doses, a positive linear adjustment was determined. At the dose of $0.04 \mathrm{~g} \mathrm{Ca} \mathrm{L}^{-1}$ substrate, the leaf dry mass was equal to $3.5 \mathrm{~g}$ plant $^{-1}$ (Figure 3H).

Albino-Garduño et al. (2008) did determine a linear raise in the percentages of leaf dry mass of cut gerberas cultivated in pots with the higher Ca supplies. A significant positive correlation was calculated between the end number of leaves and the leaf dry mass $(\mathrm{r}=0.86)$ and the leaf area and the leaf dry mass $(\mathrm{r}=0.98)$, a clear indication that gerbera plants with a higher number of leaves also presented a higher leaf area and, because of that, had a higher photosynthetic activity.

\section{Conclusions}

The different doses of nitrogen and calcium influence in an independent manner the growth and development of gerbera plants cultivated in pots, and supplying the plants with $0.14 \mathrm{~g} \mathrm{~N} \mathrm{~L}^{-1}$ and $0.04 \mathrm{~g} \mathrm{Ca} \mathrm{L}^{-1}$ substrate every 15 days is recommended.

\section{Author contribution}

MM: Conceptualization, data curation, formal analysis, investigation, methodology, software, validation, writing - original draft, writing - review and editing. EMP: Data curation, formal analysis, investigation, methodology. WH: Data curation, formal analysis, investigation, methodology. GS: Conceptualization, supervision, validation, visualization, writing - review and editing. RJB: Conceptualization, supervision, validation, visualization, writing - review and editing.

\section{Acknowledgements}

Our gratitude to Conselho Nacional de Desenvolvimento Científico e Tecnológico (CNPq) for the doctorate degree scholarship granted to the first author. 


\section{References}

ALBINO-GARDUÑO, R.; MANCERA, H.A.Z.; POSADAS, L.M.R.; VILLA, M.S.; MORALES, A.C. Response of gerbera to calcium in hydroponics. Journal of Plant Nutrition, v.31, n.1, p.91-101, 2007. https://doi. org/10.1080/01904160701741958

BRASIL. Instrução Normativa $\mathrm{n}^{\circ} 17$, de 21 de maio de 2007. Aprova os métodos analíticos oficiais para análise de substratos e condicionadores de solos. Diário Oficial da União, Seção 1, p. 8, 24 maio 2007.

CASTRO, A.C.R.; LOGES, V.; COSTA, A.S.; CASTRO, M.F.A.; ARAGÃO, F.A.Z.; WILLADINO, L.G. Hastes florais de helicônia sob deficiência de macronutrientes. Pesquisa Agropecuária Brasileira, v.42, n.9, p.12991306, 2007.

DE BOODT, M.; VERDONCK, O. The physical properties of the substrates in horticulture. Acta Horticulturae, v.26, p.37-44, 1972. https://doi.org/10.17660/ ActaHortic.1972.26.5

ESTATCAMP. Portal do Action. 2020. Available at: $<$ http://www.portalaction.com.br> Accessed on: Mar 10, 2020.

FARIAS, A.P.; ALBUQUERQUE, A.W.; MOURA FILHO, G.; REIS, L.S. Produtividade da Heliconia psittacorum $\mathrm{x}$ Heliconia pathocircinada cv. Golden Torch sob diferentes fontes de adubação orgânica. Revista Brasileira de Engenharia Agrícola e Ambiental, v.17, n.7, p.713-720, 2013. https://doi.org/10.1590/S1415-43662013000700004

FERREIRA, D.F. SISVAR: Sistema de análise de variância. Versão 5.6. Lavras: Universidade Federal de Lavras, 2020. Available in <https://des.ufla.br/ danielff/ programas/sisvar.html> Accessed on: Mar 20, 2020.

INSTITUTO BRASILEIRO DE FLORICULTURA (IBRAFLOR). Padrão de Qualidade de Gérbera de Corte. Ibraflor, 2020. Available in $<\mathrm{http}$ ://veiling.com.br/ uploads/padrao/gerbera-fc.pdf $>$ Accessed on: Mar 5, 2020.

LIN, J.A.; SUSILO, H.; LEI, J.Y.; CHANG, Y.C.A. Effects of fertilizer nitrogen shortly before forcing through flowering on carbon-nitrogen composition and flowering of Phalaenopsis. Scientia Horticulturae, v.252, p.61-70, 2019. https://doi.org/10.1016/j.scienta.2019.02.006

LUDWIG, F.; FERNANDES, D.M.; GUERRERO, A.C.; FERREIRA, G.A.; POHLMANN, V. Methods of potassium contents evaluation in the substrate solution and gerbera leaves. Ornamental Horticulture, v.25, n.3, p.238-246, 2019. https://doi.org/10.1590/2447-536x.v25i3.1535

LUDWIG, F.; FERNANDES, D.M.; MOTA, P.R.D.; VILLAS BÔAS, R.L. Macronutrientes em cultivares de gérbera sob dois níveis de fertirrigação. Horticultura Brasileira, v.26, n.1, p.68-73, 2008. https://doi. org/10.1590/S0102-05362008000100013

MERCURIO, G. Gérbera cultivation in greenhouse. Netherlands: Schreurs, 2002. 206p.

MILANI, M.; PRADELLA, E.M.; HEINTZE, W.; SCHAFER, G.; BENDER, R.J. The effects of supplemental nitrogen and calcium on the quality and postharvest life of cut gerbera. Ornamental Horticulture, v.25, n.4, p.365-373, 2019. https://doi.org/10.1590/2447-536x.v25i4.2028

OLIVEIRA, S.F.; MELLO, S.C.; MINAMI, K. Influência do cálcio e do silício, via fertirrigação, na qualidade de hastes florais de gérbera. Ornamental Horticulture, v.18, n.2, p.163-170, 2012. https://doi.org/10.14295/rbho.v18i2.460

PAULINO, A.S.; ALBUQUERQUE, A.W.; MOURA FILHO, G.; PEREIRA, F.R.S. Helicônia "Golden Torch": Produtividade e qualidade pós-colheita sob diferentes fontes e doses de silício. Revista Brasileira de Engenharia Agrícola e Ambiental, v.17, n.6, p.615-621, 2013. https:// doi.org/10.1590/S1415-43662013000600007

SANTOS, F.T.; LUDWIG, F.; COSTA, L.A.M.; COSTA, M.S.S.M.; REMOR, M.B.; SILVA, P.E.R. Growth analysis of potted gerbera conducted with mineral fertilization and organic fertigation. Ciencia e Investigación Agraria, v.43, n.1, p.111-120, 2016. https://doi.org/10.4067/S071816202016000100010

TAIZ, L.; ZEIGER, E.; MOLLER, I.M.; MURPHY, A. Fisiologia e Desenvolvimento Vegetal. Porto Alegre: Artmed, 2017. 888p. 